\title{
INTERNATIONAL ENVIRONMENTAL LAW AND THE ROLE OF INDIGENOUS PEOPLES IN PROTECTED AREAS: HOPE FOR CREATIVE SOLUTIONS IN A SETTING OF ESTABLISHED INCOMPATIBILITY
}

\author{
A. FLEISCHHAUER \& H. DETLEF KAMMEIER \\ World Heritage Studies Programme, Brandenburg University of Technology (BTU), Cottbus, Germany.
}

\section{ABSTRACT}

This article is an attempt at presenting the complex subject matter in three main parts, with an emphasis on recent developments and changes in international environmental legislation: (I) The first two sections briefly introduce indigenous peoples and a classification of those protected areas (PAs) where conflictual conditions arise, followed by an overview of international environmental law in section 3. (II) Section 4 draws up a typology of the problems, with selected case studies to illustrate the existing conflicts as well as possible solutions. (III) Sections 5 and 6 then explore the emerging paradigm shift and the way forward where the potential of indigenous peoples for better managing the world's natural resources is highlighted. The article ends with a cautiously optimistic conclusion.

Keywords: biodiversity conservation, environmental legislation, governance types, social and cultural issues, traditional knowledge.

\section{INTRODUCTION}

Over the past two decades, two global movements have brought the issues concerning indigenous peoples to greater public attention.

1. One movement is the continuous human rights activism of international organizations and the ceaseless efforts of indigenous peoples themselves supported by a number of NGOs, which brought to light the reality of ethnocide, the oppression and discrimination of indigenous groups all over the world.

2. The other movement is focused on environmental issues - the vulnerability of nature and its fragile equilibrium, global warming and climate change, excessive logging in tropical forests, overexploitation of natural resources and the destruction of ecosystems, man-made catastrophes like hazardous mining activities and frequent oil pollutions, and purely natural catastrophes, such as the recent tsunami that hit South Asia.

These events triggered a new perception of nature and an increasing interest in indigenous and tribal societies that have a strong attachment to their land and live in apparent harmony with their environment. Indigenous peoples are more and more perceived as an element of fertile nostalgia, a longing for things that cannot be found in conditions of modernity, particularly in those countries that call themselves 'advanced'. The rapid decrease in biological and cultural diversity has led to the interest of scientists and environmentalists in the unique ways in which indigenous peoples perceive, use and manage their natural resources. For environmental protection, indigenous peoples have now been discovered as useful partners due to their ingenious traditional knowledge systems.

Rationale and justification for this article: As the long descriptive title of this article suggests, the authors firmly believe that there is hope in sight, despite the long established incompatibility of international laws and the restricted role indigenous peoples are commonly allowed to play in managing natural resources. The subject matter touched upon in the article is cutting across the 
realms of international law, natural science, cultural sciences, social anthropology, and - 'heritage management', as an emerging field which is not quite as established as a branch of scientific knowledge as the previously mentioned professions.

As is often the case in such cross-disciplinary discourse, one group of readers finds some parts of the material 'old hat' albeit viewed from a new angle, while other groups of readers are more than familiar with precisely those things that are new to the first group. Thus the inherent challenge for the kind of base-line research on which this article was written is that it is next to impossible to make a radically new contribution, while the work of critically examining the state of the art in itself constitutes an original research contribution. In the authors' opinion, it is necessary to do this kind of ground work - bringing together hitherto separate views and establishing a new perspective for a complex cross-cutting set of issues to facilitate the work of the 'new multi-disciplinary conservation specialist'. This is what we have tried to do before summarizing our research results.

It is perhaps trivial to state this at the outset, but - as we would hope to show - it is very difficult to accomplish the dual principle of good and acceptable management of cultural and natural heritage resources in practice - to meet the dual criteria of being environmentally sustainable and socially equitable. Given the constraints of a journal article, the essay is limited to the main conceptual issues of the complex subject matter, without offering a comprehensive treatise here (For a recent comprehensive coverage of the subject, refer to [1]).

\subsection{Defining indigenous peoples}

Although indigenous peoples generally deny the need for a definition, the term is used here as a working definition based on the ILO Convention 169 (Article 1(a)), concerning Indigenous and Tribal Peoples (adopted 1989): 'Tribal peoples in independent countries whose social, cultural and economic conditions distinguish them from other sections of the national community, and whose status is regulated wholly or partially by their own customs or traditions or by special laws or regulations' (http://www.unhchr.ch/html/menu3/b/62.htm). Indigenous peoples belong to most disadvantaged groups of peoples in the world today. They comprise about $5 \%$ of the current world population, spread across more than 70 countries on all five continents and are characterized by the distinctiveness of their political, economic, social and cultural organizations in regard to the nationstates that incorporate them. Indigenous peoples' cultural expressions, their world views, beliefs, social systems, traditional knowledge are extremely vulnerable, as well as the ecosystems in which they live.

\subsection{Indigenous peoples and international law}

Since the international Indigenous Movement appeared at the international horizon about 25 years ago as a form of political resistance against the inequalities indigenous peoples continuously endure, this global movement is engaged in a simultaneous struggle for autonomy and survival in a world dominated by national governments and international markets. It is an expression of resistance to the dominant culture of the wider society and its homogenizing or assimilationist demand, based on the belief that there is only one correct, true or normal way to understand and structure the relevant areas of life.

Meanwhile indigenous peoples range as a political category in international law. They have achieved their own fora at the United Nations (e.g. the UN Working Group on Indigenous Populations, the Permanent Forum on Indigenous Issues). In spite of the UN's recent emphasis on 
multiculturalism, cultural diversity, cultural identity and holism the reluctance of the International Community to consider indigenous peoples as equal partners prevents the adoption of standard-setting instruments, which may enable those peoples to intervene in international as well as in national politics. Two examples of indigenous aspirations of recognition prove the present state of stagnation in the attitude of the International Community: the UN Draft Declaration on the Rights of Indigenous Peoples, which took over a decade to draft and has not been signed yet, and the attempt to establish a World Heritage Indigenous Peoples Council of Experts (WHIPCOE) as an advisory body to the Convention, which was rejected by the World Heritage Committee in 2002.

\section{PAs OF THE WORLD}

In 2003 the United Nations List of Protected Areas contained 102,102 PAs worldwide, covering 18.8 million $\mathrm{km}^{2}$. In 1994 IUCN adopted the current definition of 'protected area': 'An area of land and/or sea especially dedicated to the protection and maintenance of biological diversity, and of natural and associated cultural resources, and managed through legal or other effective means' ([2], p. 8). The best known PA type is the 'national park', but nowadays there are many more categories of such areas. The world's first national park, the Yellowstone Park, was established in 1872. The belief in an untouched wilderness was one of the basic principles of the PAs movement but this view of 'pure' nature was based on the ignorance of the traditional relationship between people and their habitat. Indeed, in the past, the designation of a PA took place mostly without the expressed consent of their inhabitants.

Since its foundation in 1948, IUCN (The World Conservation Union) constitutes an international network of PA experts and is the major advisory body to the UN in regard to environmental issues. It plays a focal role in the paradigm shift of conservation policies that took place during the 1990s. IUCN was at the forefront in promoting that indigenous peoples sometimes have a better knowledge and understanding of the natural values in PAs than some conventional scientific considerations, and that they are an indispensable part of sustainable conservation.

The growth in the global PAs network in the past 30 years reflects an increasing political commitment to conserving the Earth's remaining biodiversity. Diverse management objectives also reflect the high social and cultural values that societies place on them. Because PAs vary in nearly every respect, IUCN has developed an elaborate system of Protected Area Management Categories in 1994, based on different combinations of objectives for which they are managed. The variety of objectives can be summarized under four headings: nature conservation, science, visitor opportunities (recreational, educational, cultural, spiritual), and local and indigenous needs.

Within the very large total figure of the UN List, 68,066 PAs have been classified by the IUCN Management Categories, as shown in Table 1.

Much of the lands designated as 'national PAs' was, and still is, owned, occupied or inhabited by indigenous peoples. Of the national parks in Latin America $84 \%$ are inhabited by indigenous peoples and $90 \%$ of PAs in Europe are seasonally used by pastoral people grazing their flocks. Of those areas 30\% are permanently inhabited most of them being located in Northern and Western Europe ([3], p. 59). Only recently it was conceded that those traditional stakeholder groups constitute a hitherto underestimated potential for sustainable development and management, especially for the IUCN Categories I b, II, III and V, and VI.

Indigenous communities often have complex practices for the sustainable management of their land, even though different from those of Western science. So indigenous practices have proven to be successful, they can produce similar results as Western approaches, they can be inexpensive, and, through religious or spiritual prescriptions, can sometimes be enforced more effectively. 
Table 1: Definitions of the IUCN protected area (PA) management categories.

\begin{tabular}{|c|c|c|}
\hline Category Ia & $\begin{array}{l}\text { Strict nature reserve: } \\
\text { PA managed mainly } \\
\text { for science }\end{array}$ & $\begin{array}{l}\text { Area of land and/or sea possessing some } \\
\text { outstanding or representative ecosystems, } \\
\text { geological or available physiological features } \\
\text { and/or species, primarily for scientific research } \\
\text { and/or environmental monitoring. }\end{array}$ \\
\hline Category Ib & $\begin{array}{l}\text { Wilderness area: PA } \\
\text { managed mainly for } \\
\text { wilderness protection }\end{array}$ & $\begin{array}{l}\text { Large area of unmodified or slightly } \\
\text { modified land, and/or sea, retaining } \\
\text { its natural character and influence, } \\
\text { without permanent or significant habitation, } \\
\text { which is protected and managed } \\
\text { so as to preserve its natural condition. }\end{array}$ \\
\hline Category II & $\begin{array}{l}\text { National park: } \\
\text { PA managed mainly } \\
\text { for ecosystem protection } \\
\text { and recreation }\end{array}$ & $\begin{array}{l}\text { Natural area of land and/or sea, designated to } \\
\text { (a) protect the ecological integrity of one } \\
\text { or more ecosystems for present and future } \\
\text { generations, (b) exclude exploitation } \\
\text { or occupation inimical to the purposes } \\
\text { of designation of the area and (c) provide a } \\
\text { foundation for spiritual, scientific, educational, } \\
\text { recreational and visitor opportunities, } \\
\text { all of which must be environmentally } \\
\text { and culturally compatible. }\end{array}$ \\
\hline Category III & $\begin{array}{l}\text { Natural monument: } \\
\text { PA managed mainly for } \\
\text { conservation of specific } \\
\text { natural features }\end{array}$ & $\begin{array}{l}\text { Area containing one or more specific } \\
\text { natural or natural/cultural feature } \\
\text { which is of outstanding or unique } \\
\text { value because of its inherent rarity, } \\
\text { representative or aesthetic qualities or } \\
\text { cultural significance. }\end{array}$ \\
\hline Category IV & $\begin{array}{l}\text { Habitat/species management } \\
\text { Area: PA managed mainly } \\
\text { for conservation intervention } \\
\text { through management }\end{array}$ & $\begin{array}{l}\text { Area of land and/or sea subject to active } \\
\text { intervention for management purposes so as } \\
\text { to ensure the maintenance of habitats and/or } \\
\text { to meet the requirements of specific species }\end{array}$ \\
\hline Category V & $\begin{array}{l}\text { Protected landscape/seascape: } \\
\text { PA managed mainly for } \\
\text { landscape/seascape } \\
\text { conservation and recreation }\end{array}$ & $\begin{array}{l}\text { Area of land, with coast and sea as } \\
\text { appropriate, where the interaction of } \\
\text { people and nature over time has produced an } \\
\text { area of distinct character with significant } \\
\text { aesthetic, ecological and/or cultural value, } \\
\text { and often with high biological diversity. } \\
\text { Safeguarding the integrity of this traditional } \\
\text { interaction is vital to the protection, } \\
\text { maintenance and evolution of such an area. }\end{array}$ \\
\hline Category VI & $\begin{array}{l}\text { Managed resource protected } \\
\text { area: PA managed mainly for } \\
\text { the sustainable use of } \\
\text { natural ecosystems }\end{array}$ & $\begin{array}{l}\text { Area containing predominantly unmodified } \\
\text { natural systems, managed to ensure long-term } \\
\text { protection and maintenance of biological } \\
\text { diversity, while providing at the same time } \\
\text { a sustainable flow of natural products and } \\
\text { services to meet community needs. }\end{array}$ \\
\hline
\end{tabular}

Source: IUCN Information sheet 3, 2002, http://www.cardiff.ac.uk/cplan/sacl [emphasis bold/italics added]. 


\section{INTERNATIONAL ENVIRONMENTAL LAW}

\subsection{Overview}

Many PAs as defined by IUCN are normally under national legislation, but they also gain recognition under several other international conventions or programs, in addition to the IUCN designation. On the UN List of Protected Areas there are thus 4,633 internationally designated sites.

The two most prominent international organizations concerned with environmental issues are United Nations Environment Programme (UNEP) and United Nations Educational Social and Cultural Organization (UNESCO).

UNEP, established in 1972, is the UN focal point for environmental action and coordination among governments, UN agencies and NGOs. During the 1990s, there was a constant flow of international political and legal documents that express concern for the destruction of the environment and cultures of indigenous peoples. The legendary UN Conference on Environment and Development in Rio (called Earth Summit) in 1992 adopted the overriding principle of 'sustainable development' which reflects the interrelatedness between environmental and human development. It should be emphasized that traditional lifestyles became a key element of this concept.

With its mandate in culture as well as in natural and social sciences, UNESCO has a long tradition in addressing sustainable development and environmental conservation questions which arise at the interface of cultural and biological diversity. From the 1980s on, UNESCO also published a number of documents dealing with the concepts of cultural diversity and cultural identity, representing very significant references in indigenous peoples' issues. Table 2 provides an overview of the most important UN conventions and programs.

\subsubsection{UNESCO Conventions}

The Ramsar Convention, 1971: The Convention on Wetlands of International Importance Especially as Waterfowl Habitat was signed in Ramsar (Iran) in 1971 [4]. This Convention provides a framework for international cooperation for the conservation of wetland habitats. A number of wetlands are also parts of national parks or World Heritage sites and are often of crucial importance for indigenous peoples' livelihood and spiritual well-being. By 2003, there were 1,305 designated wetlands on the UN List.

'Man and Biosphere Programme' (MAB), 1971: Biosphere Reserves are areas of terrestrial and coastal/marine ecosystems that are internationally recognized under UNESCO's Man and the Biosphere (MAB) Programme, initiated in 1971. This program converted the idea of a core area for strict protection surrounded by buffer and transitional zones. It aims at defining systems of traditional resource management, at indigenous rights, and at cultural survival. Today an increasing number of biosphere reserves are being established in response to the request of indigenous or rural people. They are designed to promote and demonstrate a balanced relationship between people and nature. The reserves are nominated by national governments and remain under the sovereign jurisdiction of the States where they are situated. As of 2003, there were 436 Biosphere Reserves recorded in the UN List.

Convention for the Protection of the World Cultural and Natural Heritage, 1972 [5]: In 1972 UNESCO agreed to the World Heritage Convention concerned with the preservation of humankind's cultural and natural heritage. Many natural World Heritage sites were first designated as national parks under the respective national legislation. To date, 160 natural and 24 mixed sites are inscribed on the World Heritage List. Even though the UNESCO conventions date from the early 1970s, their implementation was increasingly guided by the need to be sensitive to cultural diversity and the values of indigenous groups. 


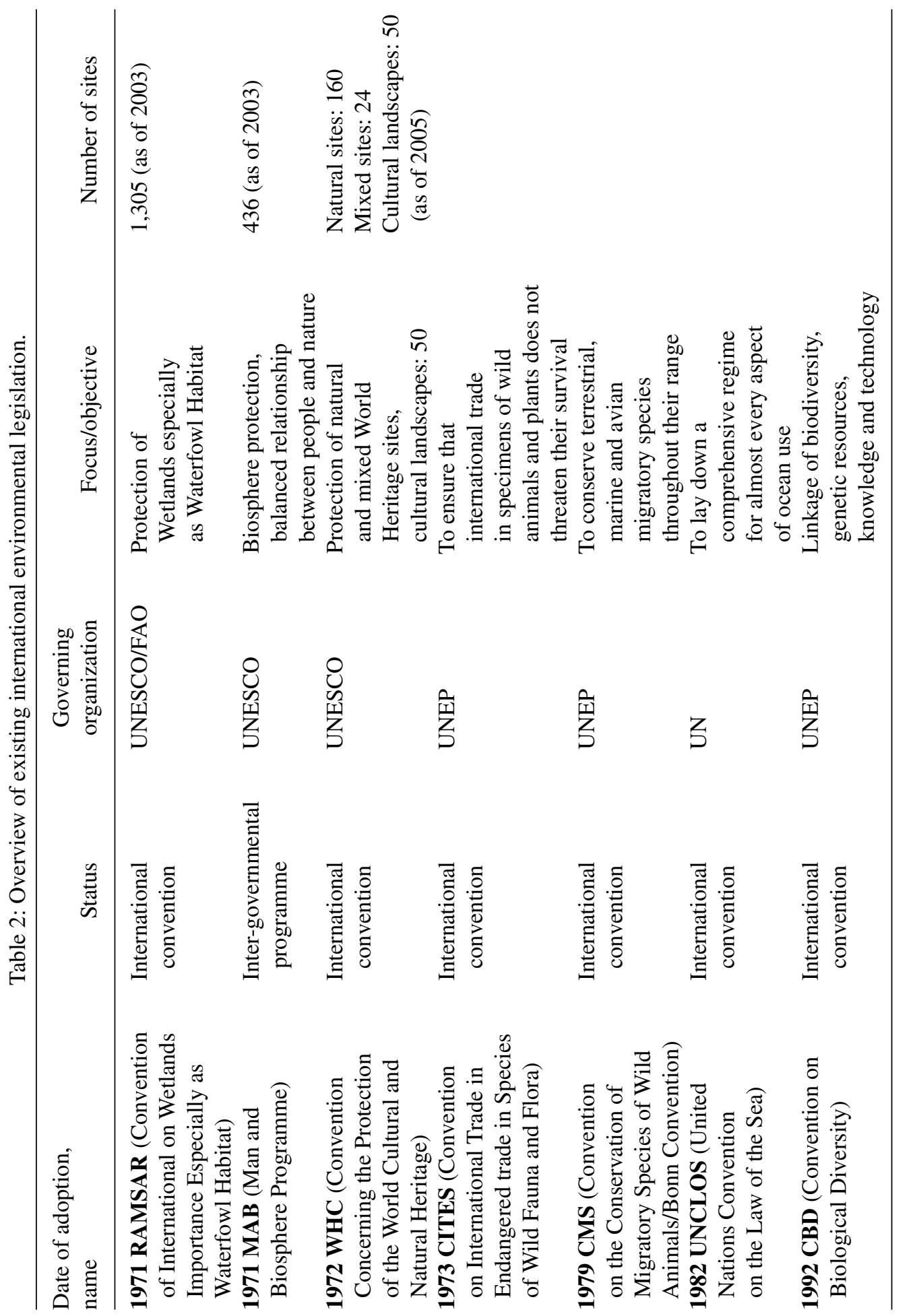


3.1.2 UNEP Conventions

The Convention on Biological Diversity (CBD), 1992 [6]: The CBD, which was one outcome of the Rio Conference is administered by the UNEP and promotes international cooperation to manage, protect and foster the sustainable use of the world's biological resources. The Convention promotes the fair and equitable sharing of the benefits that mount up from the use of genetic resources (Article 1), and is of high interest for environmentalists, biologists, nature conservationists and the global market for genetic plant resources. This is why it became one of the most controversially discussed international instruments.

The CBD preamble refers to the conservation of 'biodiversity as a common concern of humankind', a provision which is obviously taken literally by biotechnology corporations of the developed countries of the North and which caused a serious North-South confrontation at the Rio Conference. The intention of the North to turn national resources of developing countries into global commons aimed at providing the North with free access to the rich genetic pool of the developing countries of the South. The USA refused to sign the Convention, because of the controversy with developing countries about 'access and transfer of technology' covered under Article 16.

Additionally, the CBD highlights the relevance of PAs to global conservation and sustainable development. It contains a number of provisions of particular importance to indigenous peoples. Article 8 refers to in situ conservation as a state obligation (community controlled conservation, that ensures the protection of knowledge and that resources benefit first and foremost local peoples), to 'traditional lifestyles' and that these are relevant for the conservation and sustainable use of biodiversity.

Article $8(j)$ has an enormous impact on international discussions relating to the status of indigenous peoples. It refers to 'indigenous and local communities' to clarify that communities, which maintain a traditional lifestyle, are included even if they are not considered indigenous. For the first time, their central contribution to biodiversity conservation is recognized here. A Working Group on the implementation of Article 8(j) and related provisions has been established to assist signatory states to develop legislation to implement these provisions. Article 10(c) requires that each contracting party shall 'protect and encourage the use of biological resources in accordance with traditional customary practices that are compatible with conservation and sustainable use requirements'. This Article has important implications for cultural survival since particular species shape the spiritual and economic focus of many indigenous cultures. The continued customary use of such species is therefore essential to the existence of such cultures.

Article 15 ensures sovereign rights to states over their biological and genetic resources. It gives governments priority where there is a conflict between indigenous peoples' needs and needs of conservation. The solution will depend on the government's interpretation of specific cases. Because of the delicate relationship of most indigenous peoples to their state, this article is strongly rejected by them.

Related documents: A supplementary agreement to the Convention was adopted in 2000, known as the Cartagena Protocol on Biosafety which is intended at removing the flaws and uncertain parts of the CBD. This agreement seeks to protect biodiversity from the potential risks resulting from modern biotechnology. The Protocol puts the precautionary approach as a principle of international environmental law at the same level with trade related issues in the international arena. This means that formerly every release of a new product was a blind experiment with the environment and with the health of humankind. Scientific proof of harmfulness was always the task - or better the burden - of the victims. With the precautionary principle this responsibility shifted to the producer. To prove the harmlessness of a product is a very expensive and time-consuming process. No wonder that powerful industrial lobbies were able to weaken or invalidate the application of this principle - particularly in the case of genetic engineering [7]. 
The Conference of the 188 Contracting Parties (COP) to the CBD is the governing body of the Convention. It established for itself a Programme of Work (PoW) and advances the implementation of the Convention's obligations towards indigenous and local communities. The seventh Conference of Parties (COP7) [8] in 2004 framed the PoW on Protected Areas. The most significant achievement was the inclusion of a major work element on governance, participation, equity and benefit-sharing of indigenous and local communities and relevant stakeholders. It asks for constructive dialogue, exchange of experiences and information among local and non-local experts. Moreover, it calls for making use of conservation benefits to reduce poverty in indigenous and local communities.

Apart from the above described legal instruments of environmental law protecting indigenous peoples there are several international soft law instruments, among them the following two documents established at the Rio Conference in 1992.

Rio Declaration on Environment and Development, 1992 [9]: The Declaration represents an attempt to balance the sometimes contradictory concerns of both developed (the North) and developing countries (the South). Indigenous peoples were not in focus but to some extent their issues were dealt with. Principle 22 affirms the vital role of indigenous peoples in environment management. It generally stresses adequate opportunities for participation of peoples affected by development proposals.

Agenda 21: Programme on Actions for Sustainable Development, 1992 [10]: Like the Rio Declaration, Agenda 21 contains an effort to balance the environmental and development interests of almost all states of the world. Chapter 26 is entirely devoted to the role of indigenous peoples. In 'accordance with national legislation' this chapter gives indigenous peoples the opportunity for greater control over their lives and lands. It defines 'lands' as including 'the environment of the areas which the people concerned traditionally occupy' and it recognizes the importance of indigenous and local communities' knowledge and culture and the possibility of indigenous participation in the establishment or management of PAs. It recommends government action to strengthen the legal position of indigenous peoples nationally and internationally.

The CBD, the Rio Declaration and Agenda 21 give an idea as to how environmental circles understand the protection of indigenous peoples. These instruments reflect the precarious relationship between human rights protection and ecological interests. During the Rio Conference, both the human rights sphere and the environmental sphere were interlocked. However, the ecological lobby was more powerful than the human rights lobby. The protection of the rights of indigenous peoples in these documents is subordinate to and therefore restricted by regulations protecting the environment.

In the early 1990s international environmental law still tended to adopt a limited, instrumentalist, functional approach which focuses on traditional lifestyles and the use of resources from such lifestyles, because these lifestyles presumably have a beneficial impact on the environment, an attitude that has greatly changed in the course of the decade since the mid-1990s.

\subsection{A special case - the protection of landscapes}

Landscapes are a special type of PAs and express the inextricable linkages of cultural and natural aspects. In many cases, harmonious human interaction with the environment generated a sort of symbiosis, referred to as cultural landscapes and/or seascapes, which gained more international attention during the 1990s. Accordingly, protection policies focus on the long and intimate relationship between peoples and their natural environment.

3.2.1 World heritage cultural landscapes

UNESCO took a major step in 1992 to encourage the identification of cultural landscapes as a separate category worthy to be inscribed on the World Heritage List. Apart from revealing and sustaining the 
great diversity of manifestations of the interaction between humankind and its natural environment, protecting living traditional cultures and preserving the traces of those that have disappeared, the protection of cultural landscapes is also helpful in maintaining biological diversity. The "organically evolved, continuing landscape' reflects a continued existence of traditional forms of land-use and specific techniques that guarantee and sustain biological diversity in many regions of the world. Socalled 'associative landscapes' are connected in the minds of the communities with powerful beliefs and artistic and traditional customs, and embody an exceptional spiritual relationship of people with nature. They are the basis of the culture and identity of the people who live within them.

In 1993, Tongariro National Park in New Zealand became the first property to be inscribed on the List, as associative cultural landscape. It was followed by Uluru-Kata Tjuta National Park in Australia in 1994, which is of fundamental significance to Australia's Aboriginal people. In 1995 the rice terraces of the Philippine Cordilleras were inscribed as a continuing landscape.

By now there are 50 properties that are World Heritage Cultural Landscapes. However, they do not appear on the UN List of PA, due to the fact that they range under cultural properties on the World Heritage List.

\subsubsection{IUCN Category V - protected landscape/seascape}

Category V 'protected landscapes/seascapes' (as shown in Table 1 above) is unique among the six categories by making the core idea the maintenance of environmental and cultural values where there is a direct interaction between people and nature. The inclusion of the less-commonly used term 'seascape' signifies that some PAs are a mix of land and sea, an archipelago or a combination of islands. As lived-in landscapes, most of those areas have important cultural values, which are of vital significance for indigenous and local communities. Their relationship with the landscape may embody many of their spiritual beliefs and much of their cultural identity, including their relationship to their ancestors.

\section{A TYPOLOGY OF PROBLEMS}

\subsection{Perceived gaps between the international policy and the local realities}

Perhaps most significant are the gaps between the best intended, but highly sophisticated and Eurocentric international documents and recommended guidelines, and the national, regional and local conditions at the implementation level.

This is due to the fact that the instruments created by the UN to protect the rights of indigenous peoples are not ratified by many states and are not incorporated into the states' practice yet. Because many states fear their sovereignty undermined, the core provision of human rights, the right to self-determination is not yet accorded to groups which differ from the mainstream society. For many governments sovereignty, political and economical issues are still paramount over conservation. Often narrow self-interests of states (in particular of those that are cash-strapped) prevent the recognition of international standards. Violation of human rights, discrimination, unrecognized customary laws and scarce local participation are still the reality. Even legally binding conventions are only as strong as the countries that signed them want them to be.

The status of indigenous peoples in nation-states differs greatly. In North-European liberal democracies indigenous peoples enjoy relative autonomy; in North-America, Australia and New Zealand they have recently booked some striking successes concerning their territorial claims, for instance the Native Title Act in Australia in 1993. Even if these governments pursue an assimilative policy, indigenous peoples like the Scandinavian Saami, the Inuit, the American Indians, the Aborigines and the Maori have citizen status within those states, in contrast to Southeast Asian countries, which tend 
to marginalize, deny and even persecute their indigenous peoples and do not even accord citizenship status to them. Indigenous peoples enjoy their full rights only in self-governing territories, such as Greenland/Denmark and Nunavut/Canada, and in the new independent states like Timor and Papua New Guinea.

Most indigenous peoples reject the political organization of a nation-state and its values (like centralized authority, monopoly of the legitimate use of power, emphasis on science, rationality, capitalism). In contrast, indigenous peoples emphasize ideologically opposite values of particularism, spirituality, and dominance of family and elders. The primary form of organization of indigenous peoples used to be tribal or kinship ties. Their decentralized political structures are often linked in confederations and have overlapping spheres of territorial control and are conflicting with the nation-state regulations.

Two contrasting examples demonstrate how different the indigenous peoples' reality may look within national PAs (Boxes 1 and 2).

\section{Box 1: Uluru-Kata Tjuta National Park, Australia}

\section{Protection status:}

- IUCN category II national park. In 1958, Uluru was excised from an Aboriginal reserve to establish a national park.

- World Heritage Cultural Landscape. Uluru was originally nominated for World Heritage status due to its natural values in 1987 and re-nominated as an associative cultural landscape in 1994.

- UNESCO Biosphere Reserve.

Traditional ownership: In 1985, the Australian government returned ownership to its traditional Anangu owners. The inalienable freehold title to Uluru-Kata Tjuta National Park is held by the Uluru-Kata Tjuta Aboriginal Land Trust. The Park was leased back to the Director of National Parks and Wildlife. The Anangu have rights and responsibilities in relation to other Anangu clans, who are related to the land in the same way, and to ancestral beings with whom the sites and tracks are associated. The Anangu believe that the park landscape was created at the beginning of time by ancestral beings, that the Anangu are their direct descendants and that they have lived there ever since.

Management: The Park is jointly managed under direction of a Board of Management that includes a majority of Anangu traditional owners. Anangu traditional law of ecological responsibility, knowledge and religious philosophy guides everything that happens in the Park - as it has done for thousands of years. All the people and organizations involved in looking after the National Park have obligations to consider both customary law and non-Aboriginal law and interests. This obligation is also shared by Parks Australia. As such Uluru-Kata Tjuta is the prototype of a successful and innovative park management which does not only respect the traditional owners and culture but applies their rules and laws [11].

\section{Box 2: Thung Yai Naresuan/Huai Kha Khaeng Wildlife Sanctuaries, Thailand}

\section{Protection status:}

- Wildlife sanctuaries since 1974. The two sanctuaries are pure nature reserves and represent the largest legislated PA in Thailand. They form the core area of the 'Western Forest Complex' of continental Southeast Asia. The site is one of the lowland areas where large animals can cross 
from the eastern to the western edges of the forests of Huai Kha Khaeng and Thung Yai and the Myanmar forests.

- World Heritage natural site in 1991

Traditional occupation: The Karen are tribal people living in the highlands of Myanmar and Thailand. It is generally believed that they have lived there for at least two centuries. Today the Karen, like many indigenous peoples in Thailand, are under pressure to leave their forest homes. The status of the local communities is unclear; politically the Karen are minorities without civil rights.

Management: Thailand's Royal Forest Department (RFD) is convinced that continued human residence in this area will effectively cut the only major land bridge between the eastern and western parts of the forest complex. Public access to the World Heritage site is controlled by a strict permit system. The harsh preservation approach of RFD does not take into account the valuable role that resident forest peoples can have in preserving and protecting the dynamic ecosystem. In the past four decades, RFD policies have been frequently criticized in the course of re-establishing stronger roles for local communities, irrespective of the ethnicity.

The debate over the removal of the Karen escalated in 1991, when the area was the first natural site in Southeast Asia to be declared worthy of World Heritage status. The RFD restricted the traditional use of land and resources and attempted to relocate Karen villages with military support. The tribal communities of villages in Huai Kha Khaeng no longer exist within the sanctuary. All the tribal communities near the edges of Thung Yai Naresuan Wildlife Sanctuary are considered formally illegal.

Without supportive NGOs however, there is but a slim chance for the Karen to take part in the debate. Setting out their situation and justifying the legitimacy of their claims, they have to acquire a language, which is alien to them not because of the vocabulary but because of the different conceptual background [12]. (A comprehensive reference on the fate of the Karen in the context of Thai politics can be found in [13].)

This case stands for the typology of problems indigenous peoples have to endure in an Asian country. They do not have a lobby, because the influential social elite consider them as being 'primitive' and obstructive to the country's way into modernity. It is a bitter irony to the Karen that the forests that they protected and preserved for centuries are worthy of UNESCO designation, but some government and conservation officials do not recognize the Karen's unique indigenous culture as an inseparable part of that heritage. By now, the World Heritage Committee has not yet intervened in the conflict.

4.2 Confrontation - international conservation approach and the aspirations of indigenous peoples

Conservation systems are generally based on Western thinking. Many of the already existing principles and guidelines look good on paper, but do not take into account the different intellectual framework traditional and indigenous peoples are comfortable with. The different understanding of the following areas of concern frequently mounts up in misunderstanding and conflicts.

- Property, ownership, legal systems, benefit-sharing: Indigenous rights are collective rights. Collectively owned property is in most cases inalienable and impossible to transfer or to surrender. There is no distinction between ownership and mere stewardship. Customary law is due to change and cannot be codified. Benefit-sharing is based on the Euro-centric premise that resources and traditional knowledge can be valued in Dollars or Euros. 
- Authority, social status, decision-making processes: Power is the mysterious, divine energy, which exists independent of its possible user and cannot be acquired or removed by human beings. Due to the strong hierarchical structures of traditional societies dependent on lineage, gender, age and stage of initiation democratic structures based on equality seem irrelevant. In consensus oriented societies the democratic process of majority voting seems inappropriate.

- Territorial spheres: Boundaries are not fixed in a line, they may overlap and shift. For instance the Australian offshore zone is treated in Commonwealth legislation as two different legal entities land and water - whilst for Aboriginal understanding it is an integral whole.

Because of the holistic nature of all aspects of indigenous peoples' lives, their cultures consequently cannot be divided into social and cultural manifestations, traditional knowledge or the way indigenous peoples use their land and natural resources.

However, the International Community makes a clear distinction between certain areas of life. Therefore, indigenous peoples' social manifestations are a matter for the UN human rights debate with its universalistic demand. Their cultural manifestations are divided into folklore, cultural expressions (a key issue for UNESCO) and traditional knowledge, which falls within the responsibility of Intellectual Property Rights addressed to the World Intellectual Property Organization (WIPO). All mentioned approaches proved to be incompatible to assess, protect and conserve indigenous peoples' life and heritage. During the past decade international environmental conservation agencies are at the forefront in linking all these aspects, and conveying a more holistic approach.

4.2.1 Promising initiatives of indigenous peoples themselves

A great number of documents were prepared by diverse indigenous groups and NGOs during the past decade parallel to important international events such as the Rio Conference (where indigenous peoples were notably denied access). These documents are inspired by an indigenous philosophy of life as expressed by Marcos Terena, an indigenous spokesman:

Kari-Oca - Kari-Oca Conference, 1992, Brazil [14] - was born as a temple of indigenous wisdom constructed for a science and know-how that cannot be learned in an ordinary school. $[\ldots]$ The indigenous relation to nature is not only ecological or preservationist, it is particularly a relation of spiritual strength and of physical survival. Nature stands for the hope for a better future for the coming generations. The future of indigenous peoples will be the future of the white man and will be the future of Mother Earth [15].

Also in the 1993 B'okob' Declaration, Guatemala [16], indigenous peoples express the hope for a future in which 'our Mother Earth becomes healthy again', for equal relationships, mutual respect, and solidarity among individuals, peoples, and the different nations of the world. The striking occurrence of the notion 'Mother Earth' in all indigenous peoples' documents points to the idea of a custodial concept of land. This symbolic notion was incorporated in the indigenous international documents as a vehicle to refer to the distinctiveness of indigenous peoples in regard to the physical world and the indigenous peoples' holistic philosophy.

For indigenous peoples the land is the source of life. 'Mother Earth' is the center of the universe, the core of their culture, the origin of their identity as a people. 'She' connects them with their past being the home of their ancestors, with the present being provider of their material needs and with the future being the legacy they hold in trust for their children.

Most indigenous peoples live by what they call 'the Law of the Mother', a complex code of behavior that regulates human activities in harmony with plant and animal cycles, astral movements, climatic phenomena and the sacred geography of the environment [17]. 
4.2.2 Towards a people-related environmental policy

Environmentalists too increasingly subscribe to a conservation code inspired by a belief that the source of all life is the Earth. Already in 1976, the anthropologist G. Reichel-Dolmatoff [18] wrote his essay Cosmology as ecological analysis which formed the basis for every people-related environmental policy. He reports about an Amazonian Indian tribe, whose cosmologies and myth structures represent a set of ecological principles. These principles formulate a system of social and economic rules that have high adaptive value in the endeavor to maintain an equilibrium between environmental resources and the demands of society. Adaptive behavior rules control population growth, the exploitation of the natural environment, and interpersonal aggression. The tribe's awareness of the need for adaptive norms can be compared with modern system analysis: the tribal community understands the world as a system of balanced energy inputs and outputs.

However, the danger of applying this approach is that environmental protection often tends to communicate the static and idealistic image of tradition, harmony, homogeneity and stability of the 'peoples of the forest' as stewards of the land, regardless of the great number of indigenous and traditional peoples who no longer maintain a traditional or sustainable lifestyle and want to enjoy the achievements of modernity. The stereotype of the inherently ecological egalitarian hunter, the 'ecologically noble savage', may put indigenous peoples in disadvantage because human rights may be recognized and taken seriously only as long as indigenous peoples conform to the norm of ecologically conscious and responsible uses of the environment. Environmental destruction, whether the fault of those peoples or not, may then become a more legitimate argument for all sorts of repressive measures [19].

\subsubsection{New threats to indigenous and local communities}

In spite of the emerging shifts towards more adequate recognition of indigenous peoples' and local communities rights, they are confronted with yet another serious threat: the appropriation of their collective traditional knowledge of medical plants and crops that are taken by multinational companies, and their traditional songs and designs that are being commercialized for the tourism industry. Environmental law has acknowledged indigenous peoples for their maintenance of biodiversity and that there is a type of knowledge highly relevant for modern pharmacy and medicine, which is becoming more and more big business and is motivated by sheer greed.

Biotechnology and the demand for new medicines to combat cancer and AIDS have resulted in a renewed interest in collecting the medical, botanical and ecological knowledge of indigenous peoples. Using this knowledge for finding those medicines in nature and selecting plants for laboratory analysis reduces the costs and the time for discovering new products. Typically these peoples have not received any benefits from discoveries made within their territories.

The illicit and illegal appropriation of indigenous knowledge and its material is called 'biopiracy'. It occurs mainly in developing countries with a high biodiversity rate and describes the marginal modification of a plant's genetic material, which justifies intellectual property rights and exclusive contract laws of the 'new' plant. It is called 'piracy' because it is not an innovation, but a privatization of an already existing wealth of plants and knowledge.

Governments and companies are key players in the business of biotrade which refers to the movement of biological resources between countries, companies, academic institutions and individuals for potential profit. Cash poor governments in developing countries allow overseas and domestic private enterprises to operate in this sector, which might not be in the interests of the traditional knowledge holders.

By now, there is still no adequate protection means for traditional knowledge and natural resources of indigenous and local communities. Intellectual property rights (IPR) such as copyright, patent and 
trademark law governed by WIPO are Western constructs that does not encompass the needs of different cultural systems. All existing forms of legal protection through IPR are unsuitable because they are aimed at individual rights, designed to promote the dissemination and use of ideas, and provide protection of limited duration only.

The CBD does also not provide effective protection. Article 15 expects indigenous peoples to give access to their knowledge and practices but it does not protect indigenous peoples from the urge of multinational companies to patent plants and animals for their potential medicinal and agricultural values without the consent of the peoples who have protected and nurtured such resources for centuries.

\section{MANAGEMENT AND GOVERNANCE POLICIES}

\subsection{New strategies in PA management}

Since it is widely accepted that the imbalance between biodiversity conservation and the well-being of local communities who rely on natural resources affects PA conservation, new strategies of local community involvement in PA management with the minimum compromise to conservation are demanded. In recent years, there has been much advocacy for the involvement of local people as the principal stakeholders in the management of natural resources. With the emergence of an international doctrine on human rights, governments were obliged to make changes in their approach to PAs in indigenous territories. Greater democratization and the devolution of power from the center to the local level result in the fact that a central government is no longer the only agency that manages PAs.

The initiative Theme on Indigenous and Local Communities, Equity, and Protected Areas (TILCEPA), set up in 2000 by IUCN's World Commission on Protected Areas (WCPA) and its Commission on Environmental, Economic, and Social Policy (CEESP), took a major step in promoting the expansion of the 'PAs' notion, which in future should not only include government-designated areas but also small-size areas of biodiversity significance that are owned or controlled by indigenous and local communities.

This new understanding as developed at both the 5th IUCN World Parks Congress in 2003, and the PoW on Protected Areas of the CBD/COP 7 in 2004 can be summarized in the innovative concept and practice of 'governance' for PAs worldwide. A more detailed definition of 'governance' has been elaborated for the World Parks Congress:

The interactions among structures, processes and traditions that determine how power and responsibilities are exercised, how decisions are taken, and how citizens or other stakeholders have their say [20].

In the context of managing PAs, 'governance' can be qualified in at least two major ways - the governance type (Table 3) and its quality (Table 4, in Section 5.2).

New governance models and structures for PAs include various forms of collaborative management, delegated management by other parties such as NGOs and the private sector, as well as management by indigenous people or local communities. Local people are accorded a vital role in shaping management plans as is the case in Uluru-Kata Tjuta National Park.

The term 'co-management', also called 'participatory, collaborative, joint, or round-table management', stands for this strategy. The definition of co-management reads:

A situation in which two or more social actors negotiate, define and guarantee amongst themselves a fair sharing of the management functions, entitlements and responsibilities for a given territory, area or set of natural resources [21]. 
Table 3: Four types of PA governance (from [3], p. 22).

\begin{tabular}{|c|c|c|c|}
\hline $\begin{array}{l}\text { 1. Government } \\
\text { managed PA }\end{array}$ & $\begin{array}{l}\text { Federal, national, local } \\
\text { ministry or agency in charge }\end{array}$ & $\begin{array}{l}\text { Government-delegated } \\
\text { management }\end{array}$ & \\
\hline 2. Co-managed PA & $\begin{array}{l}\text { Collaborative management } \\
\text { (various forms of pluralist } \\
\text { influence) }\end{array}$ & $\begin{array}{l}\text { Joint-management } \\
\text { (pluralist management } \\
\text { board) }\end{array}$ & $\begin{array}{c}\text { Transboundary } \\
\text { management }\end{array}$ \\
\hline 3. Private PA & $\begin{array}{l}\text { Declared and run by individual } \\
\text { land-owners or by non-profit } \\
\text { organizations }\end{array}$ & $\begin{array}{l}\text { Declared and run by } \\
\text { profit organizations } \\
\text { (individual/ corporate } \\
\text { land-owners ) }\end{array}$ & \\
\hline $\begin{array}{l}\text { 4. Community } \\
\text { Conserved } \\
\text { Areas }(\text { CCA })\end{array}$ & $\begin{array}{l}\text { Declared and run by indigenous } \\
\text { peoples }\end{array}$ & $\begin{array}{l}\text { Declared and run by } \\
\text { local communities }\end{array}$ & \\
\hline
\end{tabular}

Table 4: Five key principles of 'good governance', based on the UNDP List of the characteristics of 'good governance' (from [20], p. ii).

\begin{tabular}{ll}
\hline The five 'good governance' principles & The UNDP principles \\
\hline 1. Legitimacy and voice & Consensus orientation \\
& $\begin{array}{l}\text { Participation } \\
\text { 2trategic vision, including human development } \\
\text { 2. Direction }\end{array}$ \\
and historical, cultural and social complexities \\
3. Performance & stakeholders \\
& Effectiveness and efficiency \\
4. Accountability & Accountability to the public and to institutional \\
& stakeholders \\
5. Fairness & Transparency \\
& Equity \\
& Rule of law \\
\hline
\end{tabular}

The World Parks Congress and COP 7 also recognized that community empowerment could be a significant way to enhance conservation. The work element on governance, participation, equity, and benefit-sharing of the PoW 2004 includes for the first time in an international environmental agreement an explicit recognition of Community Conserved Areas (CCAs) covered in Table 3 under point four.

CCAs are defined as

natural and modified ecosystems (including those with minimum to substantial human influence), containing significant biodiversity values, ecological services and cultural values, voluntarily conserved by indigenous, mobile and local communities through customary laws or other effective means ([3], p. 11). 


\subsection{The quality of 'governance'}

Governance is about power, relationship, responsibility and accountability. Defining the principles of 'good governance' is difficult and often controversial. However, there is an agreed list of principles, resting on the body of international law around human rights generated by the United Nations. The link between conservation, human rights and poverty reduction is of crucial importance to all these principles [20].

\subsection{The paradigm shift in management strategies for conservation}

Today it is widely accepted that conservation must embrace moral and ethical principles that encourage all those involved in the establishment and management of PAs. To recognize and involve diverse management partners and to be transparent, inclusive and accountable in decision making has a major influence on the management effectiveness and equity [22].

The paradigm shift becomes visible in the following core notions:

- From a top-down approach, in which conservation values were generally left to experts and government agencies, to a bottom-up approach, where community-based values define conservation.

- The rights-based approach, namely the respect for human rights as the most responsible approach to conservation.

- Participation has become part of the normal language of conservation. There is, however, a sensitive gradation of the notion 'participation'. In the past 'participation' was often a scheme for achieving the voluntary submission of people to PA conservation. In the 1980s 'participation by consultation' gained more attention. This meant that external agents listen to views expressed by local people, however without having the obligation to take those views on board. In the 1990s 'functional participation' aimed to involve local people after major decisions have been made, whereas in 'interactive participation' indigenous and local people take control over decisions and have a stake in maintaining structures or practices [23].

The introduction of CCA governance type, where the full authority and responsibility rests with those communities, reflects all above mentioned innovations and can be considered as the peak of the paradigm shift in conservation.

\subsection{The CCA approach}

\section{POINTING THE WAY AHEAD}

Today there are a great number of CCAs across the world. They comprise wetlands, landscapes, sacred forests and mountains, village lakes, rivers, coastal stretches and marine areas. Indigenous, mobile and local communities have a long history of conserving natural environments and species for economic, cultural, spiritual and aesthetic purposes. TILCEPA defines 'local community' as a socially and geographically defined group of people, not necessarily homogeneous, living close to the natural resources. These people may have customary rights of use, distinctive knowledge and skills and direct dependency on natural resources as individuals or groups of individuals. They have a close and unique relationship to the natural resources as a community (http://www.iucn.org/themes/ceesp/Wkg_grp/ TILCEPA/TILCEPA.htm).

The significance of CCAs encompasses following issues:

- They help to conserve critical ecosystems and threatened species.

- They are crucial to the cultural and economic survival of millions of people.

- They are often built on sophisticated ecological knowledge systems [24]. 
Nevertheless, many CCAs face enormous threats. Inappropriate development and educational models, religious intrusions, centralized political systems, commercial users, the increasing influence of market forces and the lack of political and legal support had a detrimental effect on those communities and accordingly, on the conservation state of the respective areas. CCAs may be the oldest form of PA governance, based entirely on customary rules with no governmental intervention and no incorporation in formal legislation. They are often neglected or not recognized in official conservation systems.

The third case study (in Box 3) illustrates the principal shifts that are taking place in various regions of the world, and Table 5 below demonstrates the opportunities CCAs contain for IUCN's management objectives.

\section{Box 3: Alto Fragua-Indiwasi National Park in Colombia, 2002}

The Alto Fragua-Indiwasi National Park is located at a Colombian Amazon region on the headwaters of the Fragua River. Ecologically it is a region with the highest biodiversity in the country and is one of the top hotspots of the world. The area is a sacred place for the Ingano tribe. This is one of the reasons why traditional authorities have insisted that the management should be entrusted to them.

After negotiations amongst the Colombian Government, the Association of Indigenous Ingano Councils and an environmental NGO (Amazon Conservation Team) the park was created in 2002. It protects various ecosystems of the tropical Andes, the highly endangered sub-Andean forests, endemic species and sacred sites of unique cultural value. For the first time the design and management of a PA remain exclusively in the hands of an indigenous community. The Ingano are the principal actors in the park. This has been possible due to Colombia's legislation that recognizes traditional authorities as legal subjects and represents a historic precedent for all indigenous peoples of the world, and an example to follow [25].

For IUCN's inter-commission Theme on Indigenous and Local Communities, Equity and Protected Areas (TILCEPA) CCAs are an important complement to official PA systems. TILCEPA strives for their recognition as a legitimate and effective means of conservation. Although the language and concepts of indigenous local communities and their conscious objective of management may be different from the objectives that distinguish the IUCN Protected Area Management Categories, there are various CCAs that bring similar results to the management objectives specified by IUCN. Moreover, CCAs offer models for the integration of customary laws in conservation systems, and lessons for conflict management between PAs and local people [26].

\subsection{Indigenous protected areas in Australia}

A promising officially recognized CCA model - the Indigenous Protected Area (IPA) - is put into practice in Australia. Aboriginal landowners voluntarily accepted that their land is considered as part of the National Reserve System. Because the process is voluntary, Aboriginal people can choose the level of government involvement, visitor access and the extent of development to meet their needs. Declared IPAs must have a management plan (Box 4).

The IPA Program gives equal recognition to both cultural values of indigenous people and biodiversity conservation objectives. There is a beneficial outcome for each party - the national department for environment and Aboriginal tribal communities. IPAs are attractive to some Aboriginal traditional 
Table 5: Correspondence of IUCN management categories and CCA types (from [3],p. 59).

\begin{tabular}{|c|c|}
\hline IUCN management category & CCA type \\
\hline Ia Strict nature reserve & $\begin{array}{l}\text { Sacred/forbidden or otherwise 'no-use' groves, lakes, } \\
\text { springs, mountains, islands with prohibition on uses } \\
\text { except very particular occasions }\end{array}$ \\
\hline Ib Wilderness area & $\begin{array}{l}\text { Sacred/ forbidden or otherwise 'minimal-use' areas with } \\
\text { minimal and strictly regulated use }\end{array}$ \\
\hline II National park & $\begin{array}{l}\text { Watershed forests above villages, community declared } \\
\text { wildlife sanctuaries }\end{array}$ \\
\hline III Natural monument & $\begin{array}{l}\text { Natural monuments (caves, waterfalls, cliffs, rocks) that } \\
\text { are protected by communities for religious, cultural, or } \\
\text { other reasons }\end{array}$ \\
\hline $\begin{array}{l}\text { IV Habitat/species } \\
\text { management area }\end{array}$ & $\begin{array}{l}\text { Heronries and other village tanks, turtle nesting sites, } \\
\text { community managed wildlife corridors and riparian } \\
\text { vegetation areas }\end{array}$ \\
\hline $\begin{array}{l}\text { V Protected landscape/ } \\
\text { seascape }\end{array}$ & $\begin{array}{l}\text { Traditional grounds of pastoral communities/ mobile } \\
\text { peoples, including rangelands, water points and forest } \\
\text { patches strongly inter-dependent for herd, ecosystem } \\
\text { and cultural survival; sacred and cultural landscapes and } \\
\text { seascapes, collectively managed river basins }\end{array}$ \\
\hline VI Managed resource PA & $\begin{array}{l}\text { Resource reserves (forests, grasslands, waterways, coastal } \\
\text { and marine stretches, including wildlife habitats) under } \\
\text { restricted use and communal rules that assure sustainable } \\
\text { harvesting through time }\end{array}$ \\
\hline
\end{tabular}

\section{Box 4: Toogimbie - IPA, 2004}

Toogimbie Station in south central New South Wales is owned by the Nari Nari Tribal Council (NNTC). It encompasses about 4,600 hectares of wetlands whose current conservation status is not satisfying due to its sole pastoral and agricultural use since the nineteenth century, which caused massive changes in the ecosystem and species groups in the area. Nevertheless, the New South Wales National Parks and Wildlife Service identified Toogimbie Station as having high conservation values. The declaration of the Toogimbie IPA was made under IUCN Category IV (managed resource PA) and some applicable aspects of Category II (National parks).

The ecological values of the Toogimbie wetlands consist of numerous endangered or vulnerable plant and animal species, a variety of habitat types, and wildlife. It is hoped that this area will be listed for Ramsar once it has been rehabilitated.

The cultural values of Toogimbie are bound to the traditional life of Aboriginal people as hunter and gatherers, who have developed various cultural practices over time. Aboriginal people are closely attached to the wetlands, which are home to totem animals and traditional medicines, and are used as camps and burial places. These burial sites link the health of the land and water systems and its people. Moreover, this area was part of a major trade route creating a social and cultural network. 
The NNTC will manage the area in accordance with the Toogimbie IPA Plan of Management 2004-2008. Management objectives concern the accessibility of the area to visitors and its recreational purposes. A 'place for the family' was identified as a Nari Nari priority. Aboriginal cultural sites are being protected by removing traffic and repairing the surrounding soil. Land management activities, such as weed eradication, wetland inundation, re-vegetation and feral animal control will contribute to the restoration of the land, the recovery from its pastoral use and ensure natural regeneration of the species [28].

landowners because they bring management resources without a loss of autonomy, provide public recognition of the natural and cultural values of Aboriginal land, and recognize the capacity of indigenous peoples to protect those values. IPAs are attractive to government conservation agencies because they effectively add to the nation's conservation estate. Each IPA is established for its ecological and cultural values and indigenous communities are the principal actors in the management [27].

\subsection{Sacred landscapes}

As the examples above demonstrate, indigenous peoples have always set aside special areas of nature, that they regarded as culturally or spiritually significant (e.g. burial sites as home for the ancestors, natural monuments such as mountains, forests or caves associated with formative forces of the earth). Wilderness as a sacred landscape proved to be a valuable aspect for PA management.

The international symposium headlined Conserving Cultural and Biological Diversity: The Role of Sacred Natural Sites and Cultural Landscapes was entirely devoted to this topic. Organized by UNESCO, IUCN, the Secretariat of the CBD and the Permanent Forum on Indigenous Issues, the FAO, and the United Nations University (UNU) it took place in June 2005 in Tokyo. A definition of sacred natural sites was elaborated on the occasion of this event:

Sacred natural sites are areas where nature, the divine and remembrances come together in special combinations that are particularly meaningful to a community, society or people.

Due to the international interest of biodiversity conservation in those sites the symposium participants adopted the Tokyo Declaration in which indigenous and local communities are addressed as the custodians of sacred natural sites and the holders of traditional knowledge. The Declaration calls upon authorities, managers and organizations at the national and international level to 'support and promote indigenous and local communities through the rights-based approach', to 'enhance cooperation and collaboration with their free, prior and informed consent' and to ensure their 'full and effective participation'. Their different knowledge systems, religious and spiritual practices as well as their need for sustainable livelihoods should be respected. The Tokyo Declaration urges furthermore the development of more holistic approaches and stresses for the first time the equality of both social and ecological systems [29].

\section{CONCLUSION}

Indigenous peoples are becoming more and more valued because of their unique cultural, social, intellectual and ecological systems, a fact that anthropologists are concerned with since the science overcame its Darwinist attitude. But at the international level another paradigm shift could be perceived at the end of the past millennium. In the UN new partnerships with indigenous peoples and their organizations were proposed and the views have begun to change towards increasing acceptance and respect. UNESCO strives for the protection of their cultural diversity and immense intangible 
heritage. Environmentalists acknowledge that indigenous peoples are often the better custodians of their environment and of enormous importance for sustainable development.

Concerning theories, policies and strategies, there was a progress from inflexible, reductive concepts towards living, dynamic ones. The attention given to the notion of 'holism' expresses the need of Western societies to recover some of that sense of interconnectedness and spirituality that indigenous peoples have cultivated and that is absolutely essential for their survival.

However, there is still an arduous task to tackle. Everyone who works with indigenous peoples, be it as scientist, conservationist, site manager, government official, or NGO member, needs to be prepared to enter an unfamiliar world of thoughts. Only an ongoing respectful dialogue between equal partners creates mutual understanding and acceptance.

Eventually, even the best intended conservation strategies rely heavily on the compliance of the respective states with indigenous peoples' rights and aspirations and the readiness to incorporate international standards in their domestic legal systems. All of the innovative conservation models that fully include indigenous peoples would require states that are able to move away from rigid statecentered policies, to pursue political and legal pluralism as well as to promote more multi-layered and context-sensitive conservation systems.

\section{ACKNOWLEDGMENTS}

The authors are grateful for the comments of two anonymous reviewers. They have been incorporated in this revised version of the article.

\section{REFERENCES}

[1] Fleischhauer, A., Non-compliance with an alien world: A critical analysis of indigenous peoples' rights and international heritage protection, unpublished MA thesis, World Heritage Studies programme, Brandenburg University of Technology, Cottbus, Germany, 2006.

[2] Stuart, C., Simon, B., Lucy, F., Phillip, F., \& Mark, S., United Nations List of Protected Areas. IUCN - The World Conservation Union, UNEP World Conservation Monitoring Centre, 2003.

[3] Borrini-Feyerabend, G., Kothari, A., \& Oviedo, G., Indigenous and local communities and protected areas. Towards equity and enhanced conservation. Guidance on policy and practice for Co-managed Protected Areas and Community Conserved Areas, World Commission on Protected Areas (WCPA). Best Practice Protected Area Guidelines Series No. 11, 2004, IUCNThe World Conservation Union, 2004.

[4] The Ramsar Convention, Convention on wetlands of international importance especially as waterfowl habitat, http://www.ramsar.org/key_conv_e.htm, 1971.

[5] Convention for the protection of the world cultural and natural heritage, http://www.wcmc.org. uk/igcmc/convent/wh/wh_atls.html, 1972.

[6] Convention on biological diversity, http://www.biodiv.org/convention/articles.asp, 1992.

[7] Cartagena Protocol on biosafety, http://www.biodiv.org/biosafety/default.asp

[8] Conference of Parties to the CBD (COP7), http://www.biodiv.org/decisions/default.aspx?m= COP-07\&id $=7765 \& \lg =0$

[9] UN Rio Declaration on environment and development, http://www.gdrc.org/u-gov/precaution-7. html, 1992.

[10] Recognizing and strengthening the role of indigenous people and their communities, Agenda 21: Chapter 26, http://www.un.org/esa/sustdev/documents/agenda21/english/agenda21-chapter26. htm 
[11] Layton, R. \& Titchen, S., Uluru: an outstanding Australian Aboriginal cultural landscape. Cultural Landscapes of Universal Value - Components of a Global Strategy, ed. B. von Droste et al., Jena: Gustav Fischer Verlag: Jena, pp. 174-181, 1995.

[12] Thongmak, S. \& Hulse, D.L., The winds of change: Karen people in harmony with World Heritage. The Law of the Mother: Protecting Indigenous Peoples in Protected Areas, ed. E. Kempf, Sierra Club Books: San Francisco, pp. 162-168, 1994.

[13] Reiner Buergin, Lokaler Wandel und kulturelle Identität im Spannungsfeld nationaler Modernisierung und globaler Umweltdiskurse: Die Karen im Thung Yai Naresuan Wildlife Sanctuary, einem Weltnaturerbe im Westen Thailands, Doctoral dissertation, University of Freiburg, Germany, 2002.

[14] Kari-Oca Declaration/Indigenous Peoples' Earth Charter, http://www.ipcb.org/resolutions/htmls/ karioca.htm, 1992.

[15] Terena, M., The Kari-Oca conference in Rio. Indigenous Peoples and International Institutions, ed. L. van de Fliert, Spokesman: Nottingham, p. 182, 1994.

[16] B'okob' Declaration, http://beta.austlii.edu.au/au/other/IndigLRes/1993/3/64.html, 1993.

[17] Martin, C., Introduction. The Law of the Mother: Protecting Idigenous Peoples in Protected Areas, ed. E. Kempf, Sierra Club Books: San Francisco, pp. xv-xix, 1993.

[18] Reichel-Dolmatoff, G., Cosmology as ecological analysis: a view from the rain forest, MAN, 12(2), pp. 307-318, 1976

[19] Benda-Beckmann, K. von, Environmental Protection and Human Rights of Indigenous Peoples: A Tricky Alliance. Law \& Anthropology Series 9. Kluwer Law International: London, p. 317 et sqq.

[20] Graham, J., Amos, B., \& Plumptre, T., Governance Principles for Protected Areas in the 21st Century. Institute on Governance: Ottawa, Canada, 2003.

[21] Phillips, A., Turning Ideas on their Head: The New Paradigm for Protected Areas. The George Wright Forum, 20(2), p. 93, 2003.

[22] IUCNBriefing note 7, Governance of Natural Resources - the Key to a Just World that Values and Conserves Nature? http://www.iucn.org/themes/ceesp/Wkg_grp/TILCEPA/briefing, 2004.

[23] Dawn, C. \& Colchester, M.(eds). Conservation and Mobile Iindigenous Peoples: Displacement, Forced Settlement and Sustainable Development, Berghahn Books: UK, p. 9, 2002.

[24] IUCN Briefing note 5, Community Conserved Areas. A Bold Frontier for Conservation. http://www.iucn.org/themes/ceesp/Wkg_grp/TILCEPA/CCA\%20Briefing\%20Note.pdf, 2004.

[25] Oviedo, G., World Commission on Protected Areas (WCPA). Best Practice Protected Area Guidelines Series No. 11, 2004, IUCN - The World Conservation Union, p. 53.

[26] Theme on Indigenous \& Local Communities, Equity \& Protected Areas. A joint Theme/Working Group of WCPA and CEESP, http://www.iucn.org/themes/ceesp/Wkg_grp/TILCEPA/TILCEPA. htm

[27] Indigenous Protected Areas, http://www.deh.gov.au/indigenous/ipa/declared/index.html

[28] Toogimbie IPA,http://www.deh.gov.au/indigenous/ipa/declared/toogimbie.html

[29] UNESCO International Symposium, Conserving cultural and biological diversity: the role of sacred natural sites and cultural landscapes, http://www.unesco.org/mab/SNS/symposium.htm 